Canadian

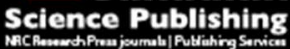

Canadian Geotechnical Journal Revue canadienne de géotechnique

\title{
Laboratory development of a vertically oriented penetrometer for shallow seabed characterization
}

\begin{tabular}{|r|l|}
\hline Journal: & Canadian Geotechnical Journal \\
\hline Manuscript ID: & cgj-2015-0165.R1 \\
\hline Danuscript Type: & Article \\
\hline Complete List of Authors: & $\begin{array}{l}\text { Sahdi, Fauzan; Universiti Malaysia Sarawak, Faculty of Engineering } \\
\text { White, David; The University of Western Australia, Centre for Offshore } \\
\text { Foundation Systems } \\
\text { Gaudin, Christophe; The University of Western Australia, Centre for } \\
\text { Offshore Foundation Systems } \\
\text { Randolph, Mark; The University of Western Australia, Centre for Offshore } \\
\text { Foundation Systems } \\
\text { Boylan, Noel; Norwegian Geotechnical Institute, }\end{array}$ \\
\hline Keyword: & clays, penetrometer, pipeline, shear strength, site investigation \\
\hline &
\end{tabular}

